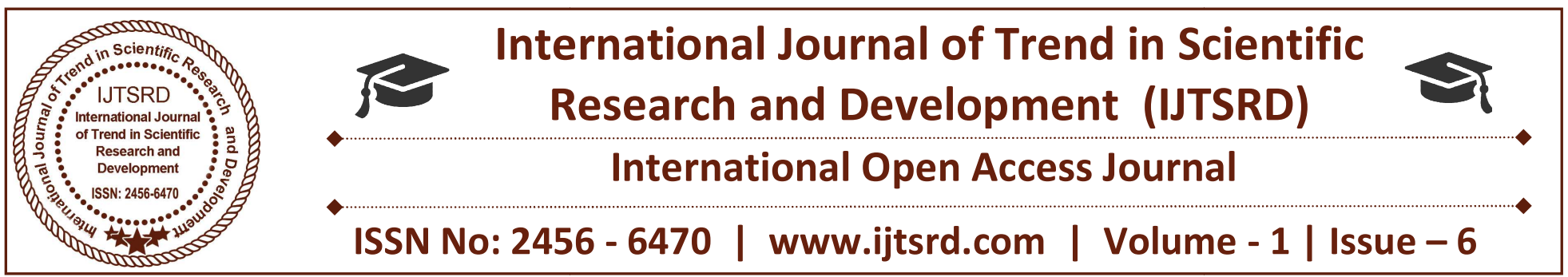

\title{
Effects of Packaging on Consumers' Purchasing Decisions
}

\author{
Sabitu Owotutu Olalekan \\ Lecturer, Business Administration Department, Ogun \\ State Institute of Technology, Igbesa
}

\author{
Adegbite G. Adewale \\ Marketing Department, Ogun State Institute of \\ Technology, Igbesa
}

\begin{abstract}
This research work is an empirical study to examine the effects of product packaging on consumers purchasing decisions and to investigate whether there is a significant relationship between packaging and brand image. Descriptive survey research was adopted through the use of a four point likert, scale questionnaire to collect data from sample of 217 respondents drew from the population of study. Researchers formulated two hypotheses: there is no significant effect between product packaging and consumers' purchasing decisions and there is no significant effect between product packaging and brand image. The hypotheses were tested with correlation and simple regression analysis and ANOVA through statistical package for social science (SPSS) and the following conclusions were drawn: that product packaging has strong effect on consumers' purchasing decisions and product packaging also have positive effect on product brand image. Based on these findings, researchers recommended that proper attention should be given to all elements of packaging to facilitate positive purchasing decisions by the consumers and product packages should be unique, attractive, cultural conformity, easy handling, protective, to ensure good product brand image.
\end{abstract}

Keywords: Product, Packaging, Consumers, Purchasing Decisions

\section{INTRODUCTION}

Packaging is an essential part of product mix and packaging decision is a crucial one in manufacturing industries for them to achieve stated marketing objectives and a keen competitive business environment.

The first point of a contact between the customer and any product is the packaging. It gives a long lasting impression not only by the product but also the manufacturer. In the word of Trott (2005), he states that anywhere there is competition in virtually products categories, packaging is often the customer's point of contact.

In the ever increasing competition of today's global market, the need for effective product promotion is crucial, and the product packaging has come to play a more important role as a brand communication vehicle. Today, virtually all goods that are manufactured or processed require some packaging in some phase of their production or distribution.

Panwar (2004), has asserted that packaging decisions are to be considered in early marketing plans as an integral part of the total marketing strategy. Packaging of consumer products is extremely important at the point of sale. It plays a major role when products are purchased. After all, it is the first thing seen before making purchasing choices and it is widely recognized that over $50 \%$ of purchasing decisions are 
made at the shelf, or point of purchase (Ferrell, 1987; Frontiers, 1996).

Lamb et al (2004) agreed that there are four most important functions of packaging one to contain and product products, promote products, and facilitate the storage, sue, and convenience of product. It is also emphasized that packaging facilitates recycling and reduce environmental damage.

\section{Research questions and Hypotheses}

The study would attempt to bring search light on the following research questions;

i. $\quad$ Is there any significant relationship between product packaging and consumer's purchasing decisions?

ii. Is there any significant relationship between packaging and brand image of a product?

In an attempt to consolidate the research questions asked by the researchers, the following null hypotheses are formulated;

i. There is no significant relationship between product packaging and consumers' purchasing decisions.

ii. There is no significant relationship between packaging and product brand image.

\section{Significant of the Study}

The study is significant because it will add to the body of knowledge in industrial setting will enrich academic world on the more recent development in the field of product packaging and purchasing decision making.

The study will also go a long way in assisting researchers that wish to continue on the study as it will serve as a reference point for review.

\section{Literature Review}

\section{Conceptual Framework}

According to Kotler (2009), packaging is all activities of designing and producing the container for a product while Zikmud and Damico (1996) say it is basically an extension of the product offered for sales. From these two definitions, one could infer that packaging is an integral part of a product and it tells much more about the product quality. Hence, packaging decisions are crucial for every product offer for sale in the market.

\section{Role of Packaging}

The four major roles that packaging is supposed to play as identified by Frey (1986) are;

i. Primary Packaging: This is the important materials enveloping the product throughout the useful life of the product.

ii. Secondary Packaging: This is the container that is used in providing additional package for the product.

iii. Display Packaging: This is the container and or wrapper intends to aid the proper display of the product a point of purchase.

iv. Transportation Packaging: This is the material normally used in packaging the product to ensure easy handling in transporting the goods from one point to another, particularly point of production, to point of sale or use.

\section{Functions for Packaging}

In order to understand the packaging elements, and determine which of the elements are most important for consumer's purchase decisions, it is imperative to discuss the functions for packaging as rightly argue by Lamb et al, (2004).

\section{$>$ Protection of Products and Consumer}

A package protects the contents as the product moves through its marketing channel and while it is in use. A packaging also prolong the shelf of life of a product, which is important to producers, middlemen, and final buyers.

\section{Facilitation of storage, use, and convenience of Products}

A major benefit of packaging is the information in it convenience to the consumers, such as directions on how to use the products and the composition of the product. Packaging convenience is defined by how consumers use the package. Simply put, convenience in packaging starts with a package that is easy to open as well as easy to close. (Hogan, 2007).

Facilitation recycling and reduce
environmental damage


The topic of consumer use of Environmental Product Information (EPI) is considered in various disciplines. Kadlecks's study (1991), indicated that $78 \%$ of consumers in the United States have showed their willingness to pay higher prices for access to environmentally friendly goods, and stressed the importance of focusing on advertising for the promotion of these products.

\section{Meaning of Consumer}

There are several definitions of consumer, however the convergent view of the writers is according to one of them Schiffan and Kanuk 2006) that is is the actions, activities display or process pass through by consumers in searching for, purchasing, using, evaluating and disposing products that they expect will satisfy their needs. On the other hand, Arnold, Price and Sinkham (2004) see it as individuals or groups acquiring, using and disposing of product, services, ideas or experiences. However, the American Marketing Association (AMA) defines it as the dynamic interaction of effect and cognition and the environment by which human beings conduct the exchange aspects of their lives.

\section{The Domain of Consumer}

According to Arnould, Price and Zinkhan (2004), domain of consumer refers to the different ways consumers can acquire, consume and dispose products, services, ideas, experiences and places.

\section{Diagram of Domain of Consumer}

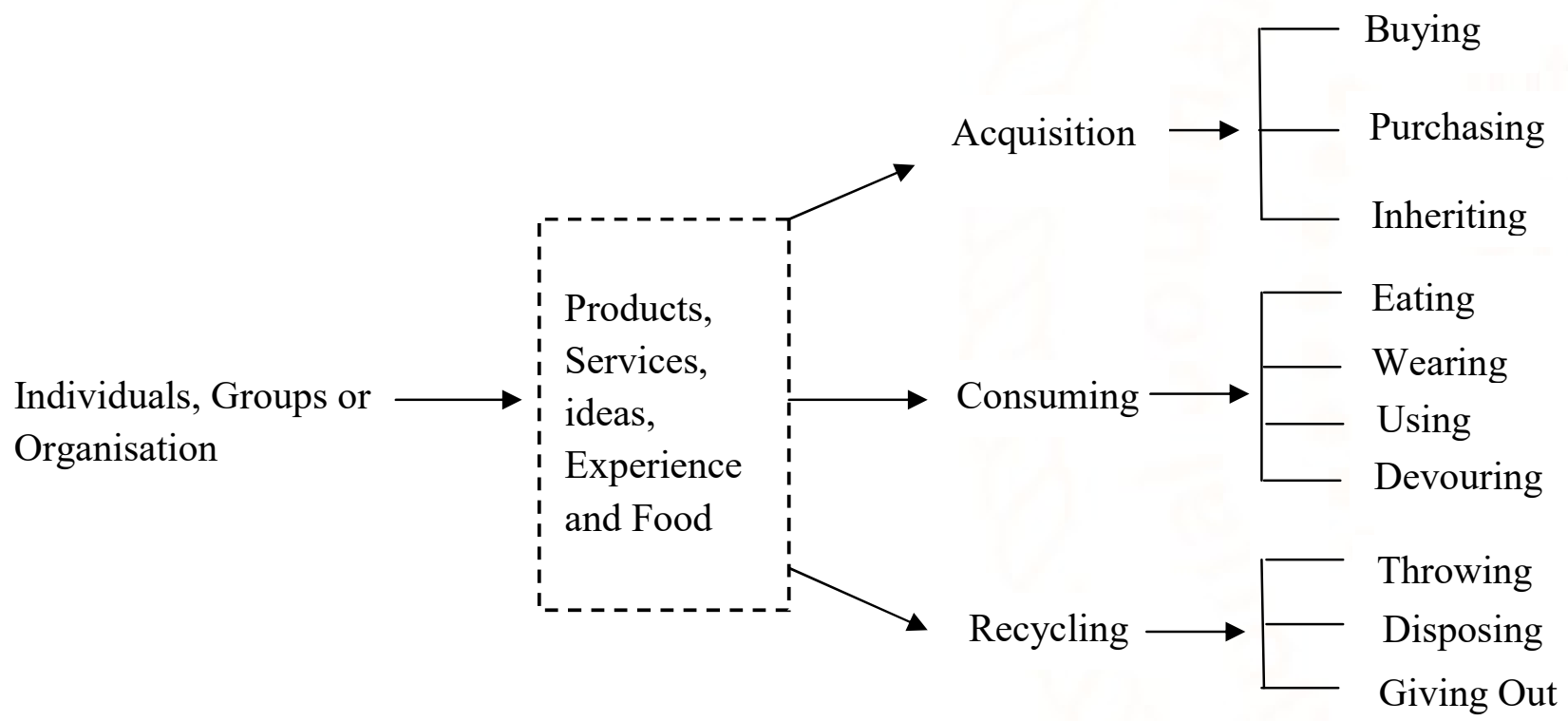

\section{Source: Adapted from Armould, Price and Zinkham 2004}

Based on the definitions of consumer, researcher realized that consumer do embark on some activities such as acquiring, which involves buying, purchasing, inheriting and so on. The consumers also involve themselves in consuming, such as eating, wearing, using, storing, devouring, etc., and in disposing in form of throwing away, depleting, recycling, giving out and so.

\section{Consumer Decision Making}

On daily basis, each of us make different, diverse and numerous decisions about every aspects of product acquisition ranging from what type of product to buy and where to buy the product (Adeyanju and Adetunji, 2015). The presence of two many types of products, brand and sources of purchase make decision making necessary.

\section{Models of Consumer Decision Making}

The models can be seen as a general framework at explaining how and why individuals behave the way they do in acquisition, consumption and disposition of products (Adeyanju and Adetunji, 2015). 


\section{Alternative Consumer Buying Decision Model}
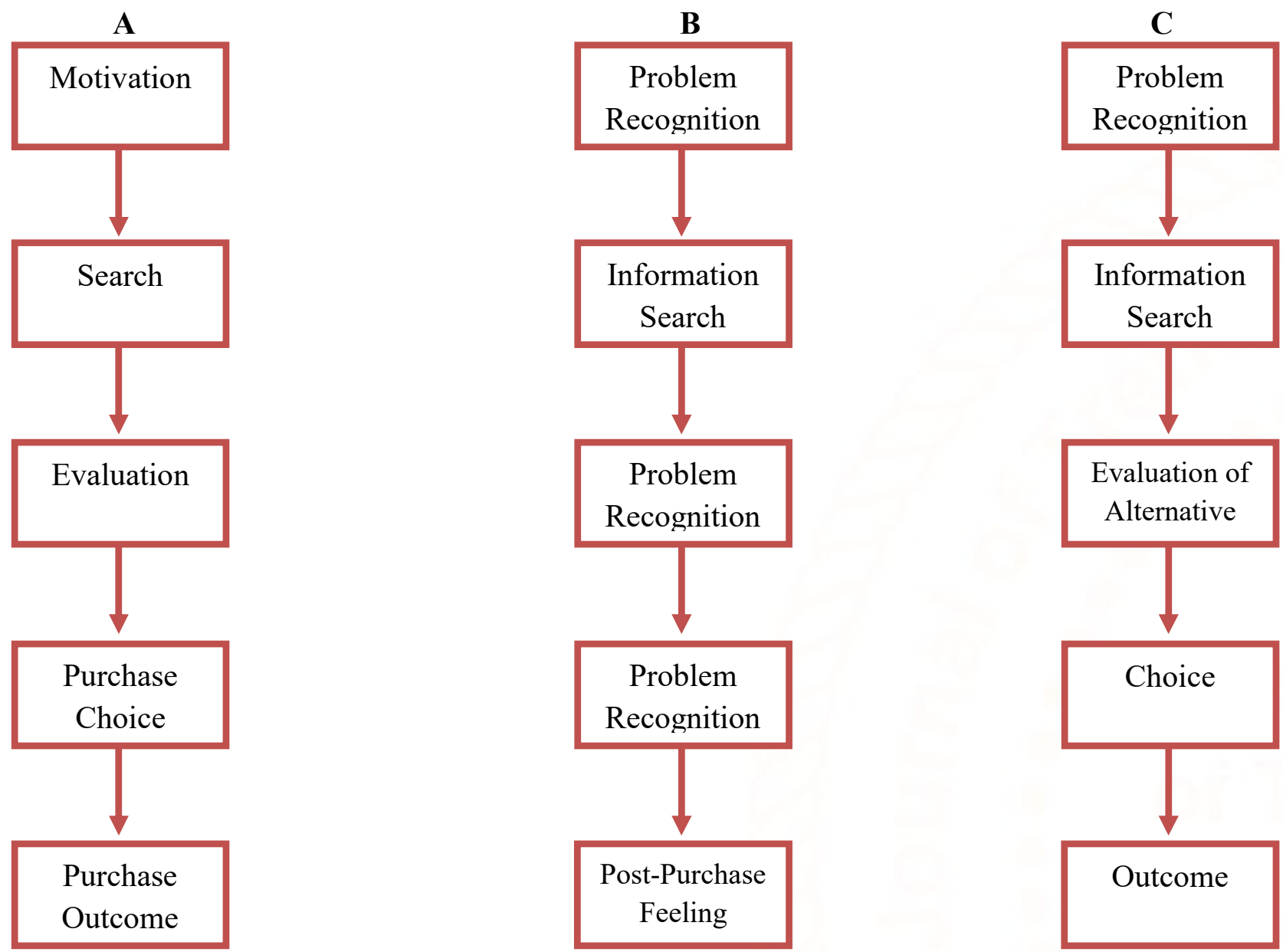

Source: Simplified 5 - stage of Model of Consumer Decision - Making called grom Kotter and Keller (2006), Lancaster and Massignhan (1990) and Eagle Kollat Blackwell (1978)

\section{Theoretical Framework}

\section{The Psychology of Product Packaging}

Consumer buying behavior can be defined as a series of activities people engage in when searching, evaluating, selecting, purchasing, using and disposing of products and services so as to satisfy their needs and desires (Larrysubero A, 2014)

In the store, the packaging acts as a gateway to the product. Consumers look at the packaging and respond to how it makes them feel at that moment. If the consumer feels that the product can potentially satisfy their needs, it influences their buying behavior.

This feeling is as a result of choices made across several cognitive stages, thus most consumers find it to be complex and overwhelming at times. Since consumers are often in state of confusion, the most important role of packaging is to alleviate their fears.
This article analyzes a typical consumer buying behavior in detail to highlight the role of packaging throughout.

\section{Packaging as the Stimulus}

Based on Ian Pavlov's classical conditioning theory, we can treat the consumer as a subject who gets exposed to a product on the shelf, wrapped in its packaging, as the stimuli. The stimuli in this case is heavily cultured to affect subject's response and achieve a desired consumer behavior. 


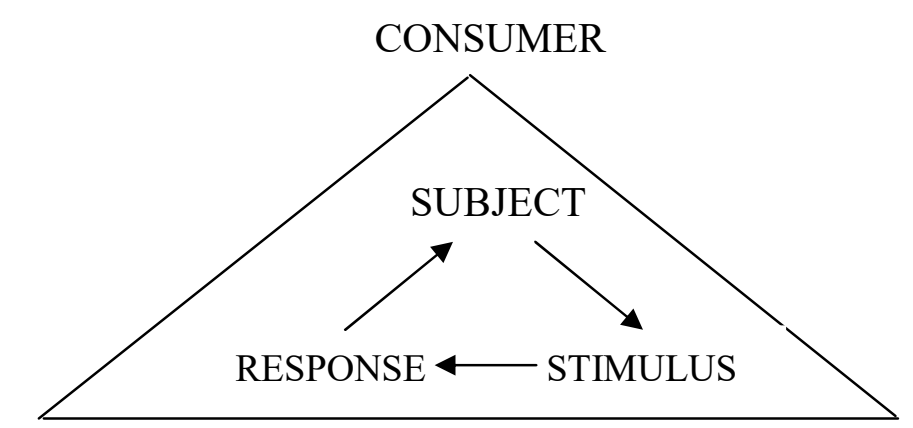

PERCEPTION

PRODUCT

\section{INSIDE PACKAGING}

Source: Pavlov's stimulus Response Theory

\section{Theories of Consumer's Buying Behavior}

According to Scott T. (2012) "Buying behavior" refers to all the decisions people and business make when they buy products or services. Several different theories have been proposed to explain and predict the buying behavior of both companies and individuals so that business owners can make the best strategic decisions and address customer want and needs.

\section{Rational Actor Theory}

According to classical economic theory, people make their buying decisions based on a rational analysis of their own self-interest in the situation. The buying behavior of an individual can be predicted by analyzing what course of action would most benefit that individual. In theory, the same principle applies to the buying decisions of groups of individual. In theory, the same principle applies to the buying decisions of groups of individuals such as businesses. However, the idea that people are rational factors in the first place has been questioned by more recent economic theories.

\section{New Institutional Economics}

According to an economic theory called new institutional economics, the rationality of any buying decision is limited by different forms of uncertainty. For instance, a person buying a ticket to an outdoor baseball game cannot know whether it will rain or not, so he cannot know whether he will receive any benefits from his purchase. The decision to buy or not to buy cannot be strictly rational under these circumstances. In many buying decisions, the potential buyer doesn't have access to as much information as the seller. For instance, if a company is considering investing some money in a development project, the developer might not share the fact that he has been having problems getting the necessary permits. The company has to decide whether or not to trust the developer, which cannot be a purely rational decision.

\section{Process Theory}

Process theory is another economic theory that seeks to explain the difference between what people would theoretically do if they were rational economic actors and what they actually do in practice. According to process theory, some buying decisions are from a selfdefensive perspective and others from an opportunistic perspective, depending on the buyer's perception of possible gains and losses. F for instance, a good bulk price on a particular item can convince a consumer to opportunistically buy more than he normally would and sometimes more than he can possibly use. On the other hand, a business owner might pass up a favorable investment simply because he doesn't trust the people trying to sell it to him.

\section{The Bullwhip Effect}

Consumer buying behavior can have a disproportionate effect on the buying behavior of businesses. For instance, if consumers demand for a particular product drops by 10 percent, the company that makes the product may switch to a less-expensive supplier for one of the component parts to make up the loss. The original supplier suffers 100 percent loss of orders from that company because of a 10 percent drop in consumer purchases. This is known as the bullwhip effect, because a small change at one end has dramatic effects on the other end. Some businesses that do not sell any product directly to the public still advertise to consumers in an attempt to influence this bullwhip effect.

\section{Methodology}

The research design chosen for this study is descriptive survey research. The population comprises all consumers of the intercontinental distrilleries products in Ogun State. Taking into consideration of distributors and retail outlets of the company.

A sample of 217 was drawn from the population using stratified random sampling.

The data collection instrument used for this study was questionnaire. The questionnaire has consists respondents' personal data while section B consists questions relevant to the research concepts. The likert 
scale used in the questionnaire had four (4) points, which are expressed as follows:

1. Strongly disagree

2. Disagree

3. Agree

4. Strongly Agree

Data collected were analyzed using correlation, regression and anova through the Statistical package for Social Science (SPSS) editor.

\section{Hypothesis Testing}

\section{Hypothesis One}

$\mathrm{H}_{\mathrm{o}}$ : there is no significant effect of product packaging on consumers 'purchasing decisions.

$\mathrm{H}_{\mathrm{a}}$ : there is significant effect of product packaging on consumers' purchasing decisions.

At 0.05 , level of significance this analysis was carried out. The model obtained from the data analysed using SPSS is written below.

$\mathrm{Yi}=\beta_{0}+\beta_{1} \mathrm{x}_{1}+€$

Where;

$\beta_{0}=$ Is the constant or intercept

$\mathrm{X}_{1}=$ Independent variable product packaging

$\mathrm{Y}=$ Dependent variable consumers' purchasing decisions

$€=$ Is the error component

Consumers' purchasing decisions $=0.529+0.210 \mathrm{x}_{1}$

Where, independent variable is product packaging $\mathrm{x} 1=$ product packaging

This is interpreted as a unit increase in the impact of product packaging leads to 0.210 increased in consumers' purchasing decisions.

\section{Model Summary}

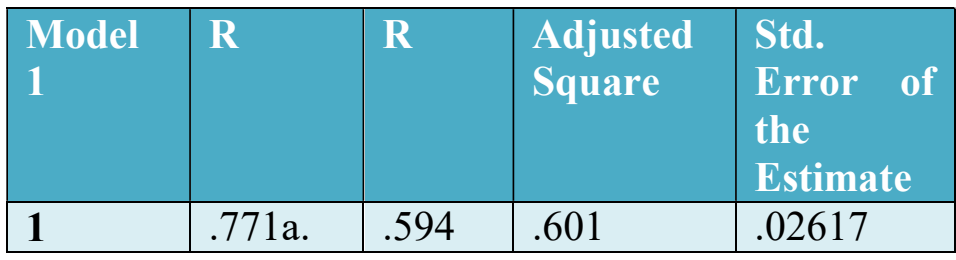

a. Predictors: (Constant), product packaging
Model Summary

\begin{tabular}{|l|l|l|l|l|}
\hline $\begin{array}{l}\text { Model } \\
1\end{array}$ & $\mathbf{R}$ & $\mathbf{R}$ & $\begin{array}{l}\text { Adjusted } \\
\text { Square }\end{array}$ & $\begin{array}{l}\text { Std. } \\
\text { Error of } \\
\text { the } \\
\text { Estimate }\end{array}$ \\
\hline $\mathbf{1}$ & $.771 \mathrm{a}$. & .594 & .601 & .02617 \\
\hline
\end{tabular}

From the above result in table above, (1) adjusted $R$ square $(0.601)$ has moderate fit. This reveals that the constructed simple regression model of the independent variables (product packaging) account for approximately $60 \%$ variance in the dependent variable (consumers' purchasing decisions). Adjusted $\mathrm{R}$ square and standard error of the estimate talk about the performance of model, however, standard error of the estimate 0.02617 showed that the model is reliable because is very close to zero. (ii) the correlation coefficient $(\mathrm{r}=0.771)$ indicated a strong positive association between the product packaging and consumers' purchasing decisions. The results on the Analysis of Variance (ANOVA) for the model are shown in Table 2.

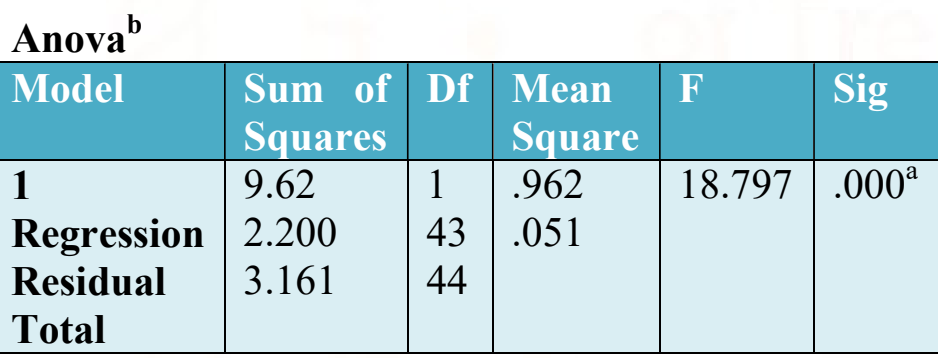

a. Predictors: (Constant), Product Packaging

b. Dependent Variables: Consumers' Purchasing

Decisions

The results of the analysis of variance (ANOVA), F (df $1,43=18.797, \mathrm{P}<0.05)$, indicated a statistically significant relationship, the coeffient or the Beta weight for the amount of standard deviation unit of change in the dependent variable was calculated. The results are as shown in table 3 below.

\section{Coefficients $^{\mathrm{a}}$}

\begin{tabular}{|c|c|c|c|c|c|}
\hline \multirow[t]{2}{*}{ Model } & \multicolumn{2}{|c|}{$\begin{array}{l}\text { Unstandardiz } \\
\text { ed } \\
\text { coefficients }\end{array}$} & $\begin{array}{l}\text { Standardiv } \\
\text { ed } \\
\text { coefficients }\end{array}$ & $\bar{T}$ & Sig \\
\hline & B & $\begin{array}{l}\text { STD } \\
\text { Error }\end{array}$ & Beta & & \\
\hline $\begin{array}{l}1 \\
\text { (Constan } \\
\text { t) } \\
\text { Product } \\
\text { Packagi } \\
\text { ng }\end{array}$ & $\begin{array}{l}.529 \\
.210\end{array}$ & $\begin{array}{l}.078 \\
.039\end{array}$ & .552 & $\begin{array}{l}4.46 \\
1 \\
4.33 \\
6\end{array}$ & $\begin{array}{l}.00 \\
0 \\
.00 \\
0\end{array}$ \\
\hline
\end{tabular}


a. Dependent Variable: Consumers' Purchasing Decisions

The standardized coefficients in Table 3 reveal that: The independent variable, product packaging value has strong positive effect on consumers' purchasing decisions because the standardized coefficient Beta value $(0.552,0.000)$ which shows statistically significant contribution for the value is less than 0.05 .

\section{Hypotheses Two}

Ho: There is so significant effect of product packaging on product brand image.

Ha: There is significant effect of product packaging on product brand image.

At 0.05 , level of significance this analysis was carried out. The model obtained from the data analysed using SPSS is written below

$\mathrm{Y}_{\mathrm{i}}=\beta_{0}+\beta_{1} \mathrm{x}_{1}+€$

Where;

$\beta_{0}=$ Is the constant or intercept

$\mathrm{X}_{1}=$ Independent variable product packaging

$\mathrm{Y}=$ Dependent variable product brand image

$€=$ Is the error component

Product Brand Image $=0.718+0.119 \mathrm{x}_{1}$

This is interpreted as a unit increase in the product packaging leads to 0.119 increases in product brand image.

\section{Model Summary}

\begin{tabular}{|l|l|l|l|l|}
\hline $\begin{array}{l}\text { Model } \\
1\end{array}$ & $\mathbf{R}$ & $\begin{array}{l}\mathbf{R} \\
\text { Squre }\end{array}$ & $\begin{array}{l}\text { Adjusted } \\
\mathbf{R} \\
\text { Square }\end{array}$ & $\begin{array}{l}\text { Std. } \\
\text { Error of } \\
\text { the } \\
\text { Estimate }\end{array}$ \\
\hline $\mathbf{1}$ & .831 & .691 & .701 & .1217 \\
\hline
\end{tabular}

a. Presictors: (Constant), Product Packaging From the result in table above, (1) Adjusted R square $(0.701)$ has moderate fit. This reveals that the constructed simple regression model of the independent variables. (Product Packaging) account for approximately 70\% variance in the dependent variable (Product brand image). Adjusted R square and standard error of the estimate 0.1217 showed that the model is reliable because is very close to zero.

b. The correlation coefficient $(\mathrm{r}=0.831)$ indicated a strong positive association between the product packaging and product brand image. The results of the Analysis of variance (ANOVA) for the model are shown in Table 2.
$\operatorname{Anova}^{b}$

\begin{tabular}{|l|l|l|l|l|l|}
\hline Model & $\begin{array}{l}\text { Sum of } \\
\text { Squares }\end{array}$ & Df & $\begin{array}{l}\text { Mean } \\
\text { Square }\end{array}$ & F & Sig \\
\hline $\mathbf{1}$ & .812 & 1 & .812 & 25.100 & $.000^{\mathrm{a}}$ \\
$\begin{array}{l}\text { Regression } \\
\text { Residual } \\
\text { Total }\end{array}$ & 3.200 & 68 & 0.3235 & & \\
\hline
\end{tabular}

a. Predictors: (Constant), Product Packaging

b. Dependent Variable: Product brand image

The results of the analysis of variance (ANOVA), F (df $1,68=25.100$, P. $<0.05$ ), indicated a statistically significant impact of product packaging on brand image. Based on this significant relationship, the coefficient for a Beta weight for the amount of standard deviation unit of change in the dependent variable was calculated. The results are as shown in table 3 below.

\section{Coefficients $^{\mathrm{a}}$}

\begin{tabular}{|l|l|l|l|l|l|}
\hline Model & \multicolumn{2}{|l|}{$\begin{array}{l}\text { Unstandardiz } \\
\text { ed } \\
\text { coefficients }\end{array}$} & $\begin{array}{l}\text { Standardiz } \\
\text { ed } \\
\text { coefficients }\end{array}$ & T & Sig \\
\cline { 2 - 6 } & $\mathrm{B}$ & $\begin{array}{l}\text { STD } \\
\text { Error }\end{array}$ & Beta & & \\
\hline $\mathbf{1}$ & .318 & .078 & .552 & 4.46 & .00 \\
(Constan & .179 & .039 & .552 & 0 \\
$\begin{array}{l}\text { t) } \\
\begin{array}{l}\text { Product } \\
\text { Packagi } \\
\text { ng }\end{array}\end{array}$ & & & 4.33 & .00 \\
\end{tabular}

a. Dependent Variable: Product Brand Image The Standardized coefficients in Table 3 reveal that: The independent variable, product packaging value has strong positive effect on product packaging value has strong positive effect on product brand image because the standardized coefficient Beta value $(0.642,0.000)$ which shows statistically significant contribution for the value is less than 0.05 .

\section{Discussion of Findings}

In the course of the investigation, it was revealed that product packaging is relevant in consumers' purchasing decisions. It has contributed greatly to the decisions taken by the consumers when they want to purchase goods. It is also discovered that there is a strong positive relationship or association between the product packaging and consumers purchasing decision. 
Hari G. and Deepak J. (2012) agreed with this finding and found out their study that packaging has an important role in marketing communications, especially from the point of sales and could be treated as one of the most important factors influencing consumer's purchase decision. Staniewska et al (2008) also supported that consumer focused mostly on the producer's trademark which is often identified with the specific brand as well as information on the product's ingredients and product benefits.

Researchers also discovered that there is a strong positive correlation between the product packaging and product brand image. And further test revealed that there is also a significant impact of product packaging on product brand image. Nilso and Ostron (2005) concurred with the finding and found out in their study that the elements of the package design affect consumer's perception differently depending on how they are combined while Mahmood and Ahmed (2013) reported that brand image does not have a positive relationship with purchase decision, brand attachment has a moderate positive relationship with purchase decision and environmental effects.

\section{Conclusion}

Results of research study regarding the effect of product packaging on a consumers packaging decision stipulated following conclusions:

Packaging could be treated as one of the most valuable tool in today's marketing communication, necessitating more detail analysis of its elements and an impact of those elements on consumer purchasing decision. A good and an attractive product packaging has greater tendency to enhance positive purchasing decision towards the product. The researcher has found that product brand image is stimulated by perfect combination of packaging elements to enhance the consumers' perception of the product in the market place. Often, packaging is perceived to be part of the product and it can be difficult for consumers to separate the two.

Packaging has a better reach than advertising does, and can set a brand apart from its competitors. It promotes and reinforces the purchase decisions not only at the point of purchase, but also every time the product is used. Packaging can even drive the brand choice of products.
As a matter of facts, people are becoming more and more demanding. Packaging has been gradually shown its important role in a way to serve consumers more by providing information and delivery functions. With its different functional to ease and to communicate with consumers, there is no doubt about increasingly important role of packaging as a strategic tool to attract consumers' attention and their perception on the product quality.

\section{RECOMMENDATIONS}

The following recommendations are therefore proffered based on the conclusion in the previous section.

i. It is highly recommended to the marketing and business units that they should pay proper attention for good packaging. If they accept or introduce the poor packaging then it could be one of the causes of product failure in the market. It is necessary to set the packaging standard and to implement strategy accordingly or better protection of a product.

ii. Great attention should be paid to promotional role of packaging to be more attractive because it plays critical role to attract more consumers, it is very important to put into consideration using variety of media to enhance this role, because consumers have different view points towards product (by designing and implanting the promotional plans timely).

iii. The package design has a very strong impact on consumers' perception. According to previous analysis, results has proved that different elements of package design played very important roles, such as picture, size, colour and shape. Consumers are willing to have easy instructions on the package, an easy handled/opened/closed package. All these elements contribute to attract consumers' attention and interest. The combination of these elements gives the product more attraction.

\section{References}

1). Adeyanju O. and Adetunji. (2012), elements of modern marketing, Lagos: Golden Cross Publications Limited.

2). Adeyanju and Adetunji (2015), Consumer Behaviour, - Lagos: Olasprint Enterprises, Somolu 
3). Ahmed, R.R., Kazim, S.S., (2011), New Product Development Strategy and Implementation Mechanism for copy Testing, "European. Journal of Scientific Research, 60 (4), 221 - 240

4). Ahmed R.R., Parmor V. and Amin M.A. (2014), Impact of product packaging on consumer's buying behavior, European Journal of Scientific Research, 122 (2).

5). Amupero, Olga, Vila, Natalia, (2006), Consumer Perceptions of product parleaging, Journal of consumer marketing, 23 (2).

6). El-Omain, Hussein, (1998), The promotional role of packaging in attracting Jordanian consumers attention to local products, HTML: LHp:/digital library.ksu.edu.sa/volM121R1923.pdf.

7). Ferrell, O.G., (1987), Marketing: Basic Concept and decisions, $5^{\text {th }}$ Edition, United States of American: Houghton Milifin Company.

8). Frontiers, (1996), Planning for consumer change in Europe 1996/1997, Henley centre,Journal of brand management, 4(2), $1-100$

9). Gafar, Mohammed, Abdkarim (2012), the impact of Human Resource Management Practices on organizational performance in Saudi Banking Sector, European Journal of Bussion and Management, 4(211) 188 - 196

10). Hansen, P.J. Knudsen, P.E. Holm, A, (2001) Human resource management practice. A PanNordic study of consumer behavior and attitude towards food labeling, "Nordic council of minister: Tema Nord 2001, 573

11). Hogan, Robert (2007) Convince strengthening three consumer brand relationship, http: www.flepackmag.com/CDA/A/Article/Special Report/BNP GWD 9 -5-2006.

12). Kadlecek, M. (1991), National Standards sought for environmental advertising, conversations, 46 (2) $54-57$.

13). Kofler, P. and Keller, R. (2006), marketing Management, (13 ${ }^{\text {th }}$ ed.), New Jersey: Pearson Prientice Hall.
14). Lamb, Charles, Hair and Card (2004), Marketing, (7th Ed).

15). Lu, Liang, Gargallo, Susana, Munar, Maria, (2007), Packaging as a strategic tool, published by Halmstead University.

16). Nawaz Ahmad, MohibBillo and Asa lachan (2012), Effect of product packaging in consumer buying decision, Journal of Business strategies 6(2) $1-10$.

17). Neff, J. Halliday, J. (2000), It is not trendy being green, Advertising Age, 71 (15)

18). Pan war, J.S., (2004), Beyond Consumer Marketing: Sectoral marketing and emerging trends, Tejeshwar Singh for response Books, New Delhi.

18). Patrick K, Ladipo, Thaddeus, Ojufayo, (2011), The multiple of packaging in the international Journal of Business Administration, 2(4) 181 189.

19). Pires, (2008), Consumer behavior: product characteristics and quality perception, available on http://mpra. Ub.un-muenclhn.de/11142/,MPRA paper no. 1142, posted 16, October 2008/10:45

20). Retie, Ruth, Brewer, Carol, (2002), The verbal and visual components of packaging design, Journal of product brand management, 9(1) 56 70.

21). Silayoi, P., Speech, M., (2004), Packaging and purchase decisions: An exploratory study on the impact of involvement level and time pressure, British food and Journal, 106 (8) 607 - 628.

22). Staniewska et al (2008), Consumer opinions on the informational and promotional function of unit packaging of diary products, Polish Journal of NaturalSciences, $23506-520$.

23). Ise, A., (1999), factors affecting consumer perception on product safety, European Journal of marketing 33 (9) $10-11$. 